\title{
APPENDIX
}

\section{Examination of Salps}

\section{By R. M. BRACHI \\ The British Food Manufacturing Industries Research Association}

Of the variety of small pelagic creatures taken by net during December 1951, only one group of species occurred in sufficient quantity for experiment. Though there is no evidence that these are eaten by whales, it may be of value to include some description of them and of the pigments they contain. Most of them (Annelids, Crustacea and Tunicates) were similar in respect to pigments, however diverse their shapes and sizes. They appeared to be composed of transparent matter, containing inclusions of the red material associated with astaxanthin, and a greenish portion found to consist of the stomach, liver, etc. In the salps these portions are closely associated. They consist of barrel-like shapes of jelly up to $5 \mathrm{~cm}$. long, and each contains a red inclusion. A number of these inclusions was dissected out, dried by grinding with anhydrous sodium sulphate and extracted in a Soxhlet apparatus with peroxide-free ether.

On removal of solvent, it was found that the ether-soluble matter was heterogeneous, and $0 \cdot 14 \mathrm{~g}$. was obtained from $37 \cdot 62 \mathrm{~g}$. of raw material. The solution in cyclohexane was yellow-green after filtration and gave maxima at 270,426 and $450 \mathrm{~m} \mu$., with a slope change at $475 \mathrm{~m} \mu$. The intensity of absorption was greatest at $426 \mathrm{~m} \mu .\left(E_{1 \mathrm{~cm} .}^{1 \%}=18 \cdot 3\right)$.

Some of the ethereal extract was saponified at room temperature with methanolic potassium hydroxide covered by a layer of $n$-hexane. The lower layer was seen to be bluish, the only indication so far that the raw material may contain astaxanthin rather than astacene.

\section{REFERENCES}

Batham, E., Fisher, L. R., Henry, K. M., Kon, S. K. \& Thompson, S. Y. (1951). Biochem. J. 48, x.

Buchsbaum, R. (1951). Animals without Backbones, vol. 2. Greenford, Middlesex : Pelican Books.

Burkhardt, G. N., Heilbron, I. M., Jackson, H., Parry, E. G. \& Lovern, I. A. (1934). Biochem. J. 28, 1698. '

Cama, H. R., Collins, F. D. \& Morton, R. A. (1951). Biochem. $J .50,48$.

Cockrill, W. R. (1951). Vet. Rec. 63, 111.

Edisbury, J. R., Gillam, A. E., Heilbron, I. M. \& Morton, R. A. (1932). Biochem. J. 26, 1164.

Embree, N. D. \& Shantz, E. M. (1943). J. Amer. chem. Soc. 65, 906.

Fisher, L. R., Kon, S. K. \& Thompson, S. Y. (1952). J. Mar. biol. Ass. U.K. 31, 229.

Gridgeman, N. T., Gibson, G. P. \& Savage, J. P. (1948). Analyst, 73, 662.
Karrer, P. (1947). Helv. chim. acta, 30, 559.

Karrer, P. \& Jucker, E. (1950). Carotenoids. London: Elsevier Publishing Co.

Meunier, P. \& Jouanneteau, J. (1948). Bull. Soc. chim. biol., Paris, 30, 185.

Morton, R. A. \& Stubbs, A. L. (1948). Biochem. J. 42, 195.

Rosenberg, H. R. (1945). Chemistry and Physiology of the Vitamins, p. 349, revised reprint. New York: Interscience Publishers Inc.

Schmidt-Nielsen, S., Sorensen, N. A. \& Trumpy, B. (1932). K. norske vidensk. Selsk. Skr. 5, 118.

Shantz, E. M., Cawley, J. D. \& Embree, N. D. (1943). J. Amer. chem. Soc. 65, 901.

Sharp, J. G. \& Marsh, B. B. (1952). Spec. Rep. Fd. Invest. Bd., Lond., no. 58. H.M.S.O.

World Health Organization (1950). Tech. Rep. Ser. no. 3, Geneva: W.H.O. 